\title{
The Norms of International Soft Law in the Legal System of the Russian Federation
}

\author{
Sergei Marochkin ${ }^{1} \&$ Rustam Khalafyan ${ }^{2}$ \\ ${ }^{1}$ Institute of State and Law, Tyumen State University, Tyumen, Russian Federation \\ 2 Administrative and Municipal Law Department, M.M. Speransky Institute for Legislation and Legal \\ Information, Irkutsk, Russian Federation \\ Correspondence: Sergei Marochkin, Institute of State and Law, Tyumen State University, 10, Semakov st., \\ 625003, Tyumen, Russian Federation. Tel: 7-909-182-3797. E-mail: mar@utmn.ru
}

Received: January 10, 2013 Accepted: January 28, 2013 Online Published: May 30, 2013

doi:10.5539/jpl.v6n2p90 URL: http://dx.doi.org/10.5539/jpl.v6n2p90

The Study was supported by the Ministry of Education and Science of Russia, Project 14.132.21.1063 "Realization of International Soft Law Norms in the Legal System of the Russian Federation".

\begin{abstract}
The norms of international "soft law" (ISL) have explicitly gained a certain importance in the legal system of the Russian Federation. Although soft law does not have legal force, its norms have become widespread within the framework of domestic jurisdiction.

The present article reflects the outcome of the holistic legal analysis of the impact of ISL as a regulatory instrument on different component parts of the domestic legal system, such as positive law, law-enforcement practice, legal theory, legal consciousness of non-state actors.

A conclusion has been formulated about the development of a definite tendency that the international component part of the Russian legal system is not only limited to "the universally-recognized norms of international law and international treaties and agreements", as it is stated in part 4 of article 15 of the Constitution of the Russian Federation. An increasingly important role is played by international norms of a non-legal nature. This appears outstanding in view of the peculiarities of "soft law".
\end{abstract}

Keywords: the legal system of the Russian Federation, international "soft law", international law (IL), legislation, courts, judicial practice, subjects of domestic law

\section{Introduction}

A review of international legal theory enables to judge that no special holistic research has been done so far on the mechanism of the operation and implementation of ISL norms within the legal system of a country. This process takes place in many states, but its scope is quite different. Therefore, the few works that concern this issue are of high interest (Fleuren, 2010: 249-250; Iwasawa, 1994: 378-388; Kunig, 1988: 59-78; Henkin, 1980: 199-212; Skubiszewski, 1975: 353-364).

Russian legal theory is no exception. Until the early 1990s, there were no surveys regarding the resort of subjects of domestic law to universal international organizations' recommendations (Kolodkin, 1986: 164-167; Lukashuk, 1987: 79-88). With the adoption of the Constitution of the Russian Federation in 1993, there arose a need for the study of ISL norms.

(a) This need is stipulated by the progressive practice of the implementation of international law. According to part 4 Article 15 of the Constitution of the Russian Federation, "the universally-recognized norms of international law and international treaties of the Russian Federation shall be a component part of its legal system". Let us lay emphasis on the fact that this is not an ordinary constitutional norm but one of the fundamentals of the Russian constitutional system. This norm is entrenched in Chapter 1 of the Constitution which has a special status and may only be changed by way of a special complicated procedure.

(b) A steady shift is visible from analyzing theoretical aspects of ISL (e.g. its notion as such and its characteristic features) to the issues concerning its operation and implementation. 
(c) There is an extension of usage of ISL by all subjects of domestic law. The constitutional principle in part 4 Article 15 is not only considered in a formally juridical way. On the contrary, courts have developed its content and rely practically on all the elements of the international normative system, such as resolutions and recommendations of international organizations, international bodies' decisions, model acts, legal positions and rulings of judicial bodies (Marochkin, 2011: 280-281).

At present, however, the study of the role of non-obligatory norms in the Russian legal system is limited to general issues or even to a mere statement of the significance of their application. As for the study of the impact of international recommendations and political arrangements on all the elements of Russia's legal system, the necessity of this study is quite rarely stressed (Malinovsky, 2009: 27-30).

Meanwhile, it is precisely the impact of ISL on different component parts of the Russian legal system (law, law-enforcement practice, legal doctrine, legal consciousness of subjects of law) that appears to be of current importance.

\section{The Doctrinal Reception of ISL and of Its Role in the Russian Legal System}

The general issues of the phenomenon analyzed have been studied by the international legal theory with scrupulous attention for quite a long time. This attention has not declined in recent years (D'Aspremont, 2009: 911-917; Shelton, 2004; Fitzmaurice \& Elias 2005: 34-47; Francioni, 2007: 167-179; Gabriel, 2009: 655-672; Guzman \& Meyer, 2009: 515-535; Hafner, 2003: 154-160; Jiang, 2009; Neuhold, 2008: 343-360; Shaffer \& Pollack, 2010: 706-799).

Within the Russian legal theory the specific character of ISL is a relatively new subject. The attitude towards it has been diverse throughout the period: from a fairly critical one (during the perestroika 1985-1991) to suspicious (in the early and mid-90s) and positive at present (Velizhanina, 2007; Vlasov, 2006: 86-99; Danelia, 2006: 73-107; Kashlatch, 2006: 26-32; Kopylov, 2007: 154-166).

The notion of ISL is used in academic literature to signify the two different phenomena: (i) the norms of international treaties indefinite in their content and (ii) provisions of non-legal acts (resolutions of international organizations, conferences etc.) (Lukashuk, 1997a: 124-133). The most widespread point of view is that "soft law" is used as the notion opposed to the legally binding "hard law". Sometimes "soft law" is simply defined by means of enumerating non-mandatory acts (recommendations of international organizations, joint statements, communiqués, decisions of intergovernmental conferences etc.) (Bezborodov, 2008: 80-93).

To our mind, the term "soft law" should not be applied to the provisions of international treaties, although declaratory, as the latter have a legal character. An international treaty often contains, alongside regulatory norms, rules of a general character which impose on parties no explicit rights and obligations. Both types are legal, but function differently.

The norms of ISL may be defined as optional, non-mandatory rules established unilaterally either by an international organization or its body (recommendations) or by states (political arrangements, decisions of intergovernmental conferences), recognized as principles or particular rules and implemented by stateson a voluntary basis within international or national law. ISL is an independent regulator on an international and national scale, but it may be accompanied by extra legislative measures established by statesin order to implement its regulations (Khalafyan, 2012a: 35-38).

The need for special research on the operation and implementation of ISL in the Russian legal system is determined, on the one hand, by its increasing role in the regulation of internal relations and in the development of legislation and judicial practice. On the other hand, the usage of these norms serves as one of the means of implementation of IL in Russia and allows to consider the tendencies of international regulation (Lukashuk, 1997b: 26, 27; Brusnitsin, 2011: 48-59; Zherebtsov, 2009: 13-16; Lisitsa, 2007: 150-153; Matveyeva, 2006: 62-71; Mulyun, 2009: 118-149; Myasnyankin, 2006: 71-75; Pashin, 2011: 13-15; Talimonchik, 2008: 134-141; Farkhutdinov, 2010: 122-128; Fogelson \& Rumyantsev, 2011: 42-53; Shashkova, 2010: 70-80; Yurova, 2008: 210-220).

It is noted by scholars that the usage of non-mandatory norms of international acts has a number of peculiar features distinguishing it from the usage of international legal obligations. This fact is determined by the nature of non-binding acts as well as by the features of different types of recommendations (Brizkun, 2011: 88).

In few publications on the subject, there is no unanimity of views concerning either a list of specific conditions of the operation of ISL within the Russian legal system or the general practicability of determining these conditions. Thus, Bogdan L. Zimnenko argues that, in order to make recommendations a constituent part of the domestic legal system, a state has a right to pass an act of a special or general domestic character which would 
incorporate appropriate provisions of an international document. As a result, a non-mandatory act would become obligatory for subjects of domestic law (Zimnenko, 2006: 293-297).

The above-mentioned point of view has raised objections. According to Sergei V. Bakhin, if we agree with such an approach, it follows that the content of the Russian legal system will not only be defined by the Russian Constitution but also by laws of a specific branch (Bakhin, 2008: 124-125). It seems that Sergei V. Bakhin, in his turn, considers it necessary to formulate certain requirements for the operation of the decisions of international organizations on the national territory, taking into account their increasing rule-making activity.

However, as existing practice demonstrates, courts have been considering acts of soft law exactly as recommendations. Strictly speaking, courts do not apply but use them to specify the terms they employ, to formulate and give proof of their position, to affirm or emphasize their legal argumentation. So, frequent academic discussions concerning the way and order of application of "soft law" norms, as well as their self-executive character, seem to make no sense (Marochkin, 2011: 254-255).

Therefore, we believe that the non-mandatory character of "soft law" leaves in doubt the necessity of special legal conditions or requirements for resort to its norms by subjects of domestic law. These norms may only become obligatory on the territory of the country by means of special references to them fixed in the legislation as well as on the basis of an international treaty, a decision of an international organization or a ruling by a judicial body. Despite all this, they remain non-mandatory, moral and political on the interstate level.

In this respect, it is more practicable and important to study issues concerning the reasons of reference to ISL by subjects of domestic law and to consider what this reference brings to the legislation and to the Russian legal system as a whole.

The ideas developed in the doctrine and concerning the usage of soft law norms in the national legal system increasingly gain substantial occurrence. Issues raised in this respect acquire a more applied character. Evidently, there are attempts to study the acts of ISL with a view to its conformity with national legislation and judicial practices. ISL is currently regarded as a rather progressive phenomenon for national law and order. Its regulations are considered to be met by subjects of domestic law. However, the research conducted at this stage has not been exhaustive so far, their results being primarily descriptive. Nevertheless, a fertile ground is being created for thorough comprehensive analysis of the role of ISL in the Russian legal system.

\section{The ISL Norms in the Acts of the Parliament: Impact of Soft Law on the Russian Legislation}

IL operates within domestic jurisdiction if the Constitution or the national legislation gives this possibility. The norms of IL are implemented by means of domestic law (Marochkin, 2011: 120-203; Id., 2009: 163-196; Mullerson, 1982: 56-74).

As the norms of ISL have a non-binding character, no reference rules or incorporating acts are required for their usage. Their implementation is voluntary; non-compliance with them entails no liability. However, the authority of these norms, their ability to reflect tendencies of contemporary regulation and high prevalence of ISL in international normative system are taken into account in the development of laws and regulations (Khalafyan, 2012b: 36-43). The existing legislation allows the naming of different variations of the participation of "soft norms" in legal regulation in the sphere of domestic jurisdiction.

In some cases, compliance with this or that particular soft norm may be at the discretion of a competent body. For instance, the Law "On Transplantation of Human Organs and/or Tissues" defines the conditions and order of transplantation of organs and tissues, "resting upon modern achievements of science and medical practice as well as taking into account the recommendations of the World Health Organization" (our translation) (Note 1).

The recognition of soft law norms may depend on the presence of certain conditions. For example, sub-section 4 Article 3 of the RF Penal Execution Code says that the implementation of international recommendations regarding the execution of punishments and treatment of prisoners is subject to the existence of necessary economic and social facilities (Note 2).

Some acts directly oblige to follow ISL norms. According to the Federal Law "On the Continental Shelf of the Russian Federation", applicants who receive authorization to create artificial islands, installations and constructions are obliged to maintain constant contact with the shore services of the Russian Federation and to pass current data concerning principal synoptic meteorological and hydrologic observations to the nearest Russian meteorological centre, in accordance with the standard procedures of the World Meteorological Organization (WMO) (para 2 part 4 Article 20) (Note 3).

Cases which stand apart seem to be those where compliance with soft law recommendations by subjects of 
domestic law grants the latter certain advantages. According to sub-section 1 Article 6 of the Federal Law "On Countermeasures against Illegally Gained Income Laundering (Legitimization) and Terrorism Financing", transactions with monetary funds or other property are subject to mandatory control in two cases: (i) if at least one party to a contract, a business or an individual, comes from a nation that does not follow the recommendations of the Financial Action Task Force (on Money Laundering) (FATF), or GAFI (Grouped' action financière); (ii) if indicated transactions are conducted on the account in a bank registered in such a nation (Note 4).

References to the ISL norms are used to define basic concepts and terms of a legal act. The Federal Law "On Circulation of Medicines" defines an international generic nonproprietary medicine name as "a pharmaceutical substance's name recommended by the World Health Organization" (sub-section 16 Article 4) (our translation) (Note 5).

Either a possibility or an obligation to follow ISL norms is also established to qualify the powers of the Russian Federation and its subjects or specific bodies of state authority. For instance, the RF Fundamentals of the Legislation "On Culture" stipulate that Russia implements the regulations of the UN "Declaration of the Rights of Children" concerning the specificity of a child involved in creative activity (para 10 Article 27) (Note 6).

Reference to international recommendation norms can also be stipulated in norms concerning international cooperation. According to sub-section 2 Article 70 of the Federal Law "On Communication", a procedure of financial settlements between international telecom carriers shall be established on the basis of international operating agreements and in compliance with the recommendations of international telecom organizations, Russia being a member of ones (Note 7).

Civil servants of state bodies may be obliged to allow for soft law norms and bring domestic legislation into accordance with them. There are acts that require that state bodies should be guided by ISL regulations.

The above-mentioned means of compliance with ISL norms are not identical to each other: they vary in the character and range of actions necessary for their operation. This might be explained by the specificity of social relations in a certain sphere. As a rule, statements of obligation appear in acts regulating the issues of special character.

However, references to soft law in Russian legislation have not become widespread as compared to references to the norms of IL. They seem to be rather an exception in the legislation, as they do not embrace the whole range of ISL acts used in the Russian legal system.

The practice of reference to "soft norms" within the legislation of the constituent territories of Russia is even more fragmentary. Such examples may be the Constitutions of the Adygei Republic and the Republic Buryatia as well as the Charter of Ryazan Oblast. These acts contain references to the 1948 Universal Declaration of Human Rights (UDHR) which stipulates the legal basis of adopting an act of supreme validity on the territory of the subjects of the Federation (Note 8). This recommendation is widely believed to have become an international custom.

Sometimes Russian legislation stipulates compliance with not only recommendations but decisions of international organizations in general, some of which may be of mandatory character. Thus, according to the Federal Law "On Postal Communication", "in the course of cross-border activities in the sphere of postal communication, a federal body of executive power in charge of postal communication regulation [...] provides procedures of payment [...] according to the acts of the Universal Postal Union" (para 3 Article 41, our translation) (Note 9).

Furthermore, some national acts require taking into account the generally accepted worldwide practice. Thus, according to the Preamble of the Federal Law "On Foreign Investments in the Russian Federation", this act is particularly aimed at "compliance of the legal order of foreign investments with the norms of international law and international practice of investment cooperation" (our translation) (Note 10).

In general it is noteworthy that references to ISL norms appearing in national legislation enrich the normative component part of the Russian legal system with specific rules additional to domestic and international law. As a result, international recommendations, ethical and political norms are incorporated in to domestic practice and affect, in a number of ways, the activities of both state bodies and citizens, their conduct and legal consciousness.

\section{The ISL Norms in the Acts of the President, Government, and Federal Bodies of Executive Power}

Since the Head of the State and the system of executive bodies are closely connected with politics, it is logical 
that decisions of these bodies are particularly influenced not only by recommendations, but also by international political arrangements. The practice of implementation of ISL by the executive power is also specific due to the fact that its foreign section directly participates in the development and adoption of international recommendation acts.

Let us mention that the federal legislation distinguishes international treaties from political arrangements. The procedure of conclusion and application of international treaties is regulated by the Federal Law "On International Treaties of the Russian Federation" (Note 11). The order of development and signing of international acts of other types is stipulated by the Enactment "On Development and Signing of International Intergovernmental Acts Beyond International Treaties of the Russian Federation", approved by the Government of Russia (Note 12).

In accordance with this Enactment, "International acts are composed, as a rule, in the form of declarations, memoranda, joint declarations, schemes and programs of cooperation. International acts shall not contain legally obliging statements. However, international acts may contain references to the obligations accepted by the parties to international treaties" (para 2 sub-section 3; our translation). Undoubtedly, the Enactment does not say that these agreements are subject to ratification. According to sub-section 7, "Federal bodies of executive power, within their competence, take measures aimed at the implementation of international acts. As may be required, appropriate regulatory and other legal acts are to be passed in pursuing this aim" (our translation).

According to the Enactment, international agreements are defined as by law acts within the system of domestic legal acts. According to para 2 sub-section 3, indicated international acts may not contradict the Constitution of the Russian Federation, generally recognized principles and norms of IL, international treaties of Russia, federal laws, acts of the President of Russia and of the Government of Russia, as well as international acts formerly signed on behalf of Russia and not considered as international treaties.

\subsection{President of the Russian Federation}

There are references to soft law in documents accepted by the Head of the State. Thus, the Decree of the President "On Supplementary Guarantees of Protection of the Rights, Freedoms and Legitimate Interests of Individuals Suspected or Accused of Committing Crimes" was adopted with consideration for the recommendations of the Parliamentary Assembly of the Council of Europe (Note 13).

Acts of ISL are also reflected in documents, representing a number of official standpoints concerning the goals, tasks and principal directions of state policy in a certain sphere. For instance, the "Strategy for the Development of the Information Society in Russia" "takes into account the basic provisions of the Okinawa Charter on the Global Information Society, the Declaration of Principles - Building the Information Society, the Tunis Agenda and other international documents accepted at the World Summit on the Development ofInformation Society" (our translation) (Note 14).

\subsection{The Government of the Russian Federation}

The Government of Russia plays a significant role in the implementation of soft law. As for the observance of international political norms, much importance is attached to the reciprocity principle. In accordance with the ruling of the Russian Government "On Strengthening Control Over the Export of Specific Types of Nuclear Facilities, Equipment and Technologies", uranium isotope enrichment facilities and nuclear reprocessing facilities as well as equipment and technologies related to these facilities can be exported from Russia to a non-nuclear weapon state only if the recipient state voluntarily follows the regulations of the Guiding Principles of the Nuclear Suppliers Group (NSG) and has presented to the UN Security Council a report on the application of appropriate measures of export control, in accordance with Resolution 1540 adopted on 28 April 2004 (Note $15)$.

The Russian Government systematically adopts legal acts that stipulate the observance of decisions of the Organization for Security and Co-operation in Europe (OSCE). In accordance with the ruling of the Government "On Implementation of Vienna Document 2011 on Confidence- and Security-Building Measures" was determined the order of implementation of the OSCE decision in Russia (Note 16).

Within the structure of federal bodies of executive power of the Russian Federation, special bodies of an either departmental or non-departmental characterare coming into being. As these special bodies are aimed at the implementation of the "soft" obligations, legal acts regulating their work often require that they should directly follow international political arrangements.

The establishment of special bodies in order to observe soft law norms is an example of incorporation of ISL into the legal system of Russia. For instance, the State Commission for Assistance in Achieving a Political Settlement 
of the Transnistrian Conflict, alongside domestic acts and international treaties, is also concerned with the documents of the 1999 OSCE Istanbul Summit, the 1997 Memorandum on the Principles of Normalization of the Relations between the Republic of Moldova and Transnistria signed in Moscow on 8 May 1997, and the Joint Statement of the President of Russia and the President of Ukraine in connection with the signing of the Memorandum (Note 17).

\subsection{Federal Bodies of Executive Power}

Other federal bodies of executive power, alongside the Russian Government, also participate in the process of implementation of international non-obligatory norms. Thus, within the Ministry of Health and Social Development has been formed the Workgroup on the Expert Examination of Legal Acts which establish sanitary and epidemiological requirements regarding their compliance with international standards, recommendations and other documents of international organizations (Note 18).

Rather interesting seem to be the "Methodological Recommendations concerning the Organization of Work on the Enforcement of International Legal Obligations of the Russian Federation in the Sphere of Legal Aid" adopted by the Ministry of Justice. According to sub-section 2, international cooperation in this sphere is implemented in concordance with the RF Constitution, generally recognized principles and norms of IL, international treaties, and arrangements achieved on the basis of international principles of reciprocity and politeness (Note 19).

Reference to soft law in the acts of the state power reflects the general practice of increasing usage of not only IL but also of international non-legal normsin the Russian legal system.

\section{Judicial Practice}

According to part 2 Article 118 of the RF Constitution, "judicial power shall be exercised by means of constitutional, civil, administrative and criminal proceedings".

The participation of judicial authorities in the implementation of international non-legal norms is rather significant. According to Article 3 of the Federal Constitutional Law "On the Judicial System of the Russian Federation", the unity of the judicial system is "provided by means of [...] implementation by all courts [...] of the generally recognized principles and norms of international law and international treaties [...]" (our translation) (Note 20). The practice of implementation of international acts has resulted in the development of specific approaches to the norms of soft law within the framework of each court system (the Constitutional Court, courts of general jurisdiction and a system of arbitrazh courts).

\subsection{The Constitutional Court of the Russian Federation}

The rulings of the RF Constitutional Court bring us to the thought that the Court firstly considers significant the essence and content of an international norm rather than its obligatory legalforce. The evidence of this is that the Constitutional Court uses ISL norms with similar purposes as it uses the universally recognized principles and norms of IL and international treaties. The formerly cautious approach and reluctant reference to non-obligatory norms have subsequently given way to a broader practice of their implementation for the purpose of argumentation and grounding of propositions and certain cases decisions of the Constitutional Court.

In the Russian legal theory the opinion has been expressed that international recommendations, being a component part of the rulings of the Constitutional Court, shall have binding force for all bodies and authorities. Thus, Oleg I. Tiunov, former judge at the Constitutional Court, believes that recommendations become a factor that has an impact on the final judgement, although not directly but through the force of legal propositions (Tiunov, 2004: 208-209). This standpoint is proved by the practice of constitutional proceedings.

The purposes of the usage of soft law in the Constitutional Court are various. Itsprovisions may serve as a way of filling in the gaps in law. For example, the ruling of the Constitutional Court of 23 May 1995 (Note 21) deals with the question of whether articles 2.1 and 16 of the Law of the Russian Soviet Federative Socialist Republic "On Rehabilitation of the Victims of Political Repressions" (18 October 1991) conform to the Constitution of Russia. The disputed rules established a distinction between citizens who were recognized as victims of political repressions and those directly repressed, although the same repressive measures had been applied to both. In particular, the dispute focused on the age of a person and concerned individuals who, by the time of the events in question, had not reached the age of 16 but who had been in fact subject to enforcement measures.

The Constitutional Court found it inadmissible to refuse to declare individuals under 16 as victims of repressions on political grounds. To prove this position, the Court referred to Article 26 of the International Covenant on Civil and Political Rights (ICCPR), according to which "all persons are equal before the law and are entitled 
without any discrimination to the equal protection of the law". To define a victim of a political repression, the Court turned to the 1985 Declaration of Basic Principles of Justice for Victims of Crime and Abuse of Power (Note 22). According to sub-section 18 of the Declaration, "Victims' means persons who, individually or collectively, have suffered harm, including physical or mental injury, emotional suffering, economic loss or substantial impairment of their fundamental rights, through acts or omissions that do not yet constitute violations of national criminal laws but of internationally recognized norms relating to human rights". Therefore, the absence in the national legislation of the term "a victim of a political repression" served as the grounds for referring to the act of soft law.

Consequently, ISL may be considered not a mere supplement but also a component part of a decision.

More often the Constitutional Court uses soft law for the argumentation of its conclusions. With the aid of a number of such acts, in the ruling of 28 February 2008 (Note 23) the Court conducted a legal analysis of the issues related to the constitutionally-legal status of a judge and concerning special requirements made on him, such as the possibility of early termination of powers in cases of misconduct and the significance of organizational activities in the sphere of justice. The Court took into account the 2006 Bangalore Principles of Judicial Conduct (Note 24), the 1985 Basic Principles on the Independence of the Judiciary (Note 25), the Recommendation No. R (94)12 of the Committee of Ministers of the Council of Europe on the Independence, Efficiency and Role of Judges (Note 26), as well as the European Charter on the Statute for Judges of 10 July 1998 (the latter act does not represent "soft law" but appears a result of academic research) (Note 27).

Recommendations of international organizations and their bodies play a definite role in the process of interpretation of domestic law. In his dissenting opinion on the Court ruling of 11 March 2005, judge Boris S. Ebzeev noted that such acts, although not generating legal obligations, have authority and respect and may become of significance in the process of revealing the regulatory content of appropriate principles (Note 28).

In its determination of 5 March 2009, the Constitutional Court not only proved but also interpreted, with the aid of a non-obligatory act, part 2 Article 22 of the Constitution of Russia. Part 2 says a person may not be detained for a term of more than 48 hours without the court's decision. The Constitutional Court came to the conclusion that the concept of "detention", as enshrined in the Constitution, has a generic character, i.e. it not only concerns the detention of a person for unlawful acts within criminal proceedings or administrative legislation, but also other types of detention (Note 29). According to the 1988 Body of Principles for the Protection of All Persons under Any Form of Detention or Imprisonment (the document used by the Court in this particular case), a "detained person" means any person deprived of personal liberty except as a result of conviction for an offence (Note 30).

Judicial practice provides evidence of one more trend in the sphere of Russian constitutional justice. Often enough the Constitutional Court does not limit itself to the usage of international recommendations for the purpose of argumentation of its ruling, interpretation of domestic law and filling in legal lacunas. It becomes obvious that soft law is also considered by the Court as a criterion of the constitutionality of legislation.

Thus, the Court indicated the correspondence of the obligation to indemnify victims of terrorist acts (enshrined in the Federal Law "On the Fight against Terrorism") to a number of documents, i.e. the Guidelines on Human Rights and the Fight against Terrorism adopted by the Committee of Ministers on 11 July 2002, the 1985 Declaration of Basic Principles of Justice for Victims of Crime and Abuse of Power, the 1990 Resolution on terrorist activities adopted by the United Nations Congress on Crime Prevention and Criminal Justice (Note 31).

Moreover, there are cases when the Constitutional Court acknowledges the correspondence of the Constitution as such to soft law! For instance, the Court indicated the correlation of the rights and freedoms of man and citizens enshrined in the Constitution to those set forth in the Resolution 1989/60 of 24 May 1989 of the United Nations Economic and Social Council confirming the Procedures for the Effective Implementation of the Basic Principles on the Independence of the Judiciary (Note 32) and the Declaration of the United Nations Conference on Environment and Development of 14 June 1992 (Note 33).

The norms of IL as a criterion of the constitutionality of national legislation often get positive feedback in the academic sphere and legal practice. Thus, according to Valery D. Zorkin, Chairman of the RF Constitutional Court, "References to international law add value to the decisions of the Constitutional Court, which at the same time demonstrates that it considers international law to be an essential criterion to which legislation and the courts' practice must correspond."(Note 34).

However, the norms of ISL are non-obligatory and do not have a legal character. In this connection, a question arises as to whether their usage by the Court as a means of control and examination of disputed norms, especially 
those fixed by the Constitution, is legitimate or not. Obviously, in situations of that kind the Court does not examine the lawfulness of the legislation from the standpoint of ISL, but uses references to it to show that the legislation develops under the auspices of existing international standards and trends of international regulation.

Beyond the above considerations, the provisions of ISL acts may be considered as evidence of the existence of the norms of international custom. However, the texts of the rulings of the Constitutional Court do not contain a description of international non-legalacts, so it appears difficult to come to a definite conclusion as to whether these acts used by the Court have a legal nature.

\subsection{Courts of General Jurisdiction}

As opposed to the Constitutional Court, courts of general jurisdiction pay more attention to the analysis of the nature of soft law acts. In our opinion, this may be explained by specific features of such courts. The Constitutional Court deals with matters of law itself, with no special regard to the factual circumstances of a case. Factual circumstances are the prerogative of the courts of general jurisdiction and a system of arbitrazh courts.

In accordance with part 1 Article 9 of the Federal Constitutional Law "On Courts of General Jurisdiction in the Russian Federation", the Supreme Court is the highest judicial body concerning civil, criminal, administrative and other cases belonging to the competence of courts of general jurisdiction. It supervises, in the forms stipulated by the federal law, the activity of courts of general jurisdiction and gives explanations regarding issues of judicial practice (Note 35).

In the determination of 11 October 2006, the Judicial Collegium for civil cases of the Supreme Court defined that "arguments saying that the disputed norms of the Law of Saint Petersburg contradict the Basic Principles on the Independence of the Judiciary adopted by the United Nations Congress and the European Charter on the Statute for Judges, are not based on the law. [...] The above-mentioned international legal acts are not international treaties of the Russian Federation and, therefore, do not have priority over the federal law. Neither the Basic Principles on the Independence of the Judiciary adopted by the United Nations Congress nor the European Charter on the Statute for Judges are legally binding acts for Russia" (our translation) (Note 36). At the same time, this conclusion of the Court does not appear irreproachable as it qualifies acts of soft law as legal acts.

It is noteworthy that it is not always that the Supreme Court follows this approach. Indeed, there are decisions that do not contain any description of the recommendations at all. However, the Supreme Court sometimes makes cautious attempts to give reasons of implementation of ISL. Nonetheless, such an argumentation seems to be one-off and does not become widespread.

The Supreme Court finds it possible to rule on the basis of soft law norms, reasoning this approach by the universal recognition of these international norms. This approach seems to result from a not fully apt turn of clarification in the ruling of the Supreme Court Plenum "On Application of the Generally Recognized Principles and Norms of International Law and International Treaties ofthe Russian Federation" of 10 October 2003. In accordance with sub-section 1 of the Ruling, the content of the generally recognized norms is revealed, particularly, in United Nations documents and in documents of UN specialized agencies (Note 37). It should be said, however, that the resolutions of international organizations are not the only factor proving the existence of a generally recognized principle or norm of IL. One should also take into account other forms, i.e. judicial practice, unilateral declarations of a state etc. (Ignatenko, Marochkin \& Suvorova, 2004: 26-31).

The Supreme Court does not limit itself to the list of international acts provided in the above-mentioned Ruling. Thus, Recommendation Rec (2006)2 of the Committee of Ministers of the Council of Europe to member states on the European Prison Rule was also acknowledged by the Court as a document containing generally recognized principles and norms of IL (Note 38). The lack of argumentation, however, brings us to the thought that the Supreme Courtfollows an arbitrary approach when proving the existence of generally recognized principles and norms of IL.

The need for using ISL norms, alongside with their recognition as universal by courts, is also based on the presence of an international treaty of Russia establishing an international organization (Note 39). In a word, the legitimacy of referring to soft law may be substantiated by part 4 Article 15 of the Constitution of Russia dealing with the status of IL within the Russian legal system.

Although this approach of the Supreme Court may be approved of, mere reference to the constitutional principle does not seem convincing. Despite certain similarities, the norms of soft law have some distinctive features as compared to IL. Therefore, the constitutional principle should be considered as a condition rather than the grounds of the usage of the soft norm. 
In other Decisions, the Supreme Court has distinguished other types of grounds of resort to soft law: (i) the presence of domestic acts implementing its provisions (Note 40); (ii) official publication (Note 41); (iii) membership of Russia ofan international organization, whose recommendation is subjected to implementation (Note 42); (iv) the presence in domestic legislation of certain provisions containing mentions of international recommendations.

Hereby, it is obvious that the Supreme Court uses the same grounds for reference to soft law as to IL. With such an approach, those features of ISL that made it so widespread (no legal constraints, ease of adoption and amendment, quick reception of the requirements of international relations if compared to IL) have been substantially leveled.

The usage of soft law by this Court becomes explicit when it does not only consider separate cases, but also sums up judicial practice or provides clarification concerning the application of legislation tolower courts. Providing the necessity of taking into account ISL, the Plenum of the Supreme Court prescribes lower courts to refer to international recommendations, for instance, to the 1995 Standard Minimum Rules for the Treatment of Prisoners, the 1991 UN Principles for the Protection of Persons with Mental Illness and the Improvement of Mental Health Care, the 1981 Declaration on the Elimination of All Forms of Intolerance and of Discrimination Based on Religion or Belief, the 2004 Declaration on Freedom of Political Debate in the Media adopted by the Committee of Ministers etc. (Note 44).

Such a practice of references to the resolutions and decisions of international organizations, their bodies and inter-governmental conferences may contribute to the reinforcement of opinio juris in respect of these recommendations and to further development of norms of customary IL. Meanwhile, however, in drawing the attention of lower courts to the norms of soft law, the Supreme Court does not specify or explain the reasons and grounds for using such norms. This circumstance cannot be considered acceptable because the work of the Supreme Court guides and directs the whole system of courts of general jurisdiction.

\subsection{Arbitrazh Courts}

The practice of arbitrazh courts does not abound in references to the ISL norms. Generally, arbitrazh courts take these norms into account but do not give any grounds for reference to them. Thus, in one of its documents the Supreme Arbitrazh Court of the Russian Federation only hypothesizes regarding a recommendation of the Committee of Ministers, that "Russia as a member of the Council of Europe may and, apparently, should adhere to these recommendations in the process of development and adoption of its laws" (our translation) (Note 45).

In the ruling of the Federal Arbitrazh Court of the East Siberian District of 24 March 2005, the correctness of the decision of the Arbitrazh Court of Krasnoyarsky Krai was proved by referring not only to the 1966 International Covenant on Economic, Social and Cultural Rights (ICESCR) but also to the 1993 Standard Rules on the Equalization of Opportunities for Persons with Disabilities (Note 46).

The ruling of the Presidium of the Supreme Arbitrazh Court of 9 December 2012 says that dismissing a complaint the court of first instance foundthat the requirements of the applicant were provided neither by Russian legislation nor by the 1997 International Plant Protection Convention, while the regulations of International Standards for Phytosanitary Measures (ISPMs) Guidelines for Phytosanitary Certificates - ISPM No. 12 have a recommendation character (Note 47).

The widespread use of international non-legal norms by the system of Russian courts, including the highest body of constitutional control (the Constitutional Court), reveals that the ISL norms are well-perceived in the sphere of law-making as well as in that of law-enforcement. The courts consider and implement soft law alongside IL. However, they rarely make attempts to provide argumentation of necessity or purposes for the usage of international acts of recommendation character in their decisions.

\section{Reference to Soft Law of Non-State Actors in Courts}

The rules of international soft law are not only applied by the bodies of state power. They are frequently referred to by individuals and legal entitiesas well as by other types of subjects of law. All this results from the impact of non-legal international norms on legal awareness and the sense of justice.

Thus, in the case considered by the Constitutional Court on 19 January 2005 following a petition of the Commissioner for human rights in the Russian Federation, the applicant referred to the ILO acts. In particular, he argued that the legal positions of the Court did not meet the provisions of the ILO Protection of Wages Convention No. 95 and the ILO Recommendation No. 180 on the Protection of Workers' Claims in the event of the Insolvency of their Employer (Note 48). 
Courts express different attitudes towards applications in which citizens support their position by revealing a breach of soft law. In general, there is not forbid to resorts to ISL. Therefore, it is difficult to make a clear conclusion about necessity of using ISL by non-state actors. Probably, it will depend on the specific situation and the arguments which individuals have in a trial. Despite this, we consider that ISL norms will impart the complaints of the non-state actors extra weight and moral and political force.

In some cases, the reasoning of applicants is taken into account. For instance, the Decision of Krasnoyarsky Krai court of 14 May 2010 deals with a claim to recognize a contradiction between the law of the Krasnoyarsky Krai and federal legislation (Note 49). (The Law had introduced alterations regarding the social support of veterans, rehabilitees and other categories of citizens.) The applicant party was constituted by a number of citizens, the regional social movement of Krasnoyarsk "Victims of Political Repression", the Regional Social Charity Organization of Pensioners and Persons with Disabilities "The Krasnoyarsk Association of Victims of Unlawful Political Repressions".

The grounds of the asserted claims were that the norms of the Law contradicted, particularly, the 1985 Declaration of Basic Principles of Justice for Victims of Crime and Abuse of Power. However, in the course of the judicial proceedings, the Court did not find any contradiction between the Law of the region and the international act. The Court indicated that the Law stipulates indemnities and support of victims of abuse of power in accordance with the financial possibilities of the Krasnoyarsky Krai (Region).

Considering other cases, courts have not taken into account the argumentation of applicants referring to soft law. In the determination of Constitutional Law of 23 April 2022, citizens K. and M. disputed the constitutionality of the Civil Procedural Code of the Russian Soviet Federative Socialist Republic (Note 50). According to the norm of the Code, a judge shall dismiss an application if it is not subjected to hearing and ruling according to the order of civil legal proceedings. The complaint, alongside references to the Constitution of Russia, the Universal Declaration of Human Rights, the International Covenant on Civil and Political Rights (ICCPR), the European Convention on Human Rights, the CIS Convention on Human Rights and Fundamental Freedoms, mentions the Concluding Document of the Vienna Meeting of Representatives of the Participating States of the OSCE and the Charter of Paris for a New Europe.

Dismissing this complaint, the Constitutional Court noted that references by the applicants to the provisions of the OSCE documents could not be taken into account as, by implication of part 4 Article 15 of the Constitution, they are not international treaties of the Russian Federation and do not fix generally recognized principles and norms of IL.

Both examples reveal that peculiarities of recommendations and political norms affect the possibility of their usage by private actors who are not vested with power of authority. It is not unlikely that their claims will not be taken into account. Most probably, their references to ISL acts in order to urge the state to fulfill certain actions, will be blocked by the state bodies with argumentation on the non-obligatory status of such acts. Obviously, as a result, a comparatively small number of soft norms are used in the private-law (civil) sphere.

Thus far, political norms have been primarily applied by executive bodies of state power in the process of adoption of acts aimed at implementation of international obligations, or, less often, by legislative bodies in lawmaking.

The reasons for individuals and businesses' resorting to international non-legal norms do not always seem obvious. They are likely to be connected with the nature of non-legal acts that may be misleading sometimes: acts of "soft law" are quite often perceived as legal.

\section{Conclusion}

In the Russian legal system a developing practice of implementing the norms of ISL in the regulation of legal relations has been obvious. The impact of such norms on certain components of the national legal system (domestic law, judicial practice, legal awareness and sense of justice) shows that soft law is capable of serving as a complementary assistant regulator of domestic relations alongside "hard law".

References to ISL are fixed in legislation, i.e. soft law affects the development of domestic law and contributes to the implementation of international standards and trends of international regulation. All this, in turn, may serve as evidence of opinio juris in respect of certain rules and lead, with the lapse of time, to the formation of normsof customary IL.

The usage of international political arrangements has become current in the sphere of executive power. The establishment of special bodies and the development of domestic acts aimed at implementation of political arrangements prove the significance of obligations that have not been accepted yet as norms of IL. 
Judicial practice gives the fullest evidence of the recognition and importance of international non-legal norms. It is notable that the courts of higher instances give the lower courts recommendations concerning the advisability or necessity of the application of ISL. Judges use soft law in formulating their legal positions and in cases where it is necessary to interpret generic or ambiguous legal norms.

This practice should not be considered as an alternative to IL. However, in a number of cases the norms of soft law are not considered merely as a supplementary or 'technical' accessory. These are cases when international non-legal acts contribute to filling in legal lacunas, the reinforcement of legal argumentation and the reasoning of legal positions and court rulings.

Individuals and legal entities also refer to international non-obligatory norms. However, their reference does not seem to be regularly taken into account by courts.

All the above proves a definite tendency that the presence and operation of international acts and rules in the legal system of Russia is not only limited to legal acts and rules. This process is becoming widespread and embraces other types of international documents which are sometimes not provided by the legislation. If previously the way was primarily smoothed for the operation of IL, today we can observe a broader process of not only the implementation of IL norms, but also that of ISL norms.

All this leads to an extension of the normative component of the legal system of Russia and its international component. References to soft law create a broader interaction between the domestic system and the international legal system, international standards and arrangements being developed within the latter by the international community.

The picture of the implementation of international legal norms by subjects of national law will be broader on the basis of a further study of the resort of state power, individuals and other subjects of law to international non-legal norms.

\section{References}

Bakhin, S. V. (2008). International Component of the Legal System of Russia (continuation). Jurisprudence, 1, 117-132.

Bezborodov, Y. S. (2008). International Model Norms. Moscow: Wolters Kluwer.

Brizkun, K. A. (2011). Influence of Recommendation Acts of International Organizations on Development of International-Legal and Domestic Norms of the Russian Federation (PhD Thesis). Moscow.

Brusnitsin, L. V. (2011). Federal Law 'On State Protection of Victims, Witnesses and other Participants of Criminal Proceedings' in the Light of UN Recommendations. State and Law, 1, 48-59.

D`Aspremont, J. (2009). Softness in International Law: A Self-Serving Quest for New Legal Materials. European journal of international law, 20(3), 911-917. http://dx.doi.org/10.1093/ejil/chp059

Danelia, G. R. (2006). Peculiarities of Legal Regulation of the EU Member-States Cooperation in the Field of External Policy and Defense Policy (PhD Thesis). Kazan.

Farkhutdinov, I. Z. (2010). International Investment Law: from 'Soft Law' to Treaty Norms. International Law and International Organizations, 1, 122-128.

Fitzmaurice, M., \& Elias, O. (2005). Contemporary issues in the law of treaties. Utrecht: Eleven International Publishing.

Fleuren, J. (2010). The application of public international law by Dutch courts. Netherlands International Law Review, LVII, 249-250.

Fogelson, Yu., \& Rumyantsev, S. (2011). Defense of Consumers Interests on Financial Markets by means of 'Soft Law'. Economy and Law, 1, 42-53.

Francioni, F. (2007). International «Soft Law»: A Contemporary Assessment. In V. Lowe, \& M. Fitzmaurice (Eds.), Fifty Years of the International Court of Justice: Essays in Honour of Sir Robert Jennings (pp. 167-179). New York: Cambridge University Press.

Gabriel, H. D. (2009). The Advantages of Soft Law in International Commercial Law: The role of UNIDROIT, UNCITRAL, and the Hague conference. Brooklyn Journal of International Law, 34(3), 655-672.

Guzman, A. T., \& Meyer, T. L. (2009). International Common Law: The Soft Law of International Tribunals. Chicago Journal of International Law, 9(2), 515-535.

Hafner, G. (2003). The Effect of Soft Law on International Economic Relation. In S. Griller (Ed.), International 
economic governance and non-economic concerns: new challenges for the international legal order (pp. 154-160). Wien: Springer-Verlag. http://dx.doi.org/10.1007/978-3-7091-6036-7_5

Henkin, L. (1980). Resolutions of International Organizations in American Courts. In F. Kalshoven, P. J. Kuyper, \& J. G. Lammers (Eds.), Essays on the Development of the International Legal Order: in Memory of Haro F. van Panhuys (pp. 199-212). Alphen aan den Rijn/Rockville: Sijthoff \& Noordhoff.

Ignatenko, G. V., Marochkin, S. Y., \& Suvorova, V. Y. (2004). Ruling of the Supreme Court Plenum of Russia of 10 October 2003 and International-Legal Reality. Bulletin of the RF Ministry of Justice, 4, 26-31.

Iwasawa, Y. (1994). The Relationship between International Law and National Law: Japanese experiences. In I. Brownlie, \& D. W. Bowett (Eds.), British Yearbook of International Law (pp. 378-388, 1993, Vol. 64). New York: Oxford University Press.

Jiang, L. (2009). An evaluation of soft law as a method for regulating public procurement from a trade perspective (Thesis submitted to the University of Nottingham for the degree of Doctor of Philosophy).

Kashlach, O. (2006). Norms of 'Soft' Law: Notion and Indications. Journal of International Law and International Relations, 2, 26-32.

Khalafyan, R. M. (2012a). Conception of International 'Soft Law' in International-Legal Doctrine. Euroasian Juridical Journal, 2, 35-38.

Khalafyan, R. M. (2012b). Influence of 'Soft Law' on the International Legal System. Academics Juridical Journal, 2, 36-43.

Kolodkin, R. A. (1986). International Recommendation Norms (on Example of the UN General Assembly Resolutions-Recommendations) ( $\mathrm{PhD}$ Thesis). Moscow.

Kopylov, M. N. (2007). Introduction to International Ecological Law: Training Supplies. Moscow: RUDN.

Kunig, P. (1988). Relevance of Resolutions and Declarations of International Organizations for Municipal Law. In G. I. Tunkin, \& R. Wolfrum (Eds.), International Law and Municipal Law: Proceedings of the German-Soviet Colloquy on Internat. Law at the Inst. Für Internat. Rechtan d. Univ. Kiel, 4 to 8 May 1987 (pp. 59-78). Berlin: Duncker u. Humblot.

Lisitsa, V. N. (2007). 'Soft Law' as Regulator of International Investment Relations. Jurisprudence, 4, 150-153.

Lukashuk, I. I. (1987). UN General Assembly Resolutions and Municipal Law. In G. I. Tunkin, \& R. Wolfrum (Eds.), International Law and Municipal Law: Proceedings of the German-Soviet Colloquy on Internat. Law at the Inst. Für Internat. Rechtan d. Univ. Kiel, 4 to 8 May 1987 (pp. 79-88). Berlin: Dunckeru. Humblodt.

Lukashuk, I. I. (1997a). International Law Norms in the International Normative System. Moscow: Spark.

Lukashuk, I. I. (1997b). International Law Norms in the Legal System of Russia. Moscow: Spark.

Malinovsky, O. N. (2009). On Influence of the International Organizations Acts on Human Rights on the Legal System of Russia. Philosophy of Law, 6, 27-30.

Marochkin, S. Yu. (2011). Operation and Realization of International Law Norms in the Legal System of the Russian Federation. Moscow: Norma, Infra-M.

Marochkin, S. Yu., \& Tuzmukhamedov, B. R. (2009). International Law and National Law: Correlation and Interaction. In V. I. Kuznetsov, \& B. R. Tuzmukhamedov (Eds.), International law - A Russian Introduction (pp. 163-196). Utrecht: Eleven Publishers.

Matveeva, T. V. (2005). To the Issue on 'Soft Law' in Regulation of International Private Law Relations. State and Law, 3, 62-71.

Mullerson, R. A. (1982). Correlation of International and National Law. Moscow: International Relations.

Mulyun, V. N. (2009). Peculiarities of International and Domestic Law Correlation in the Activity of the World Trade Organization, International Monetary Fund and the World Bank Group (PhD Thesis). Moscow.

Myasnyankin, V. N. (2006). Application of International Organizations Acts in the Russian Legal System. Juridical World, 3, 71-75.

Neuhold, H. (2008). Variations on the Theme of «Soft International Law». In I. Buffard ... (Eds.), International law between universalism and fragmentation: festschrift in honour of Gerhard Hafner (pp. 343-360).

Leiden: Martinus Nijhoff Publishers. http://dx.doi.org/10.1163/ej.9789004167278.v-0.104 
Pashin, S. A. (2011). Beijing Rules and Some Provisions of Russian Criminal Legislation (Comparison of Models of Curator and Punitive Justice). Issues of Juvenile Justice, 4, 13-15.

Shaffer, G. C., \& Pollack, M. A. (2010). Hard vs. Soft law: Alternatives, Complements, and Antagonists in International Governance. Minnesota Law Review, 94(3), 706-799.

Shashkova, A. V. (2010). Russia and Recommendations of FATF. Moscow Journal of International Law, 2, 70-80.

Shelton, D. (Ed.). (2004). Commitment and Compliance: The Role of Non-Binding Norms in the International Legal System. New York: Oxford University Press.

Skubiszewski, Kr. (1975). Recommendations of the United Nations and Municipal Courts. British Yearbook of International Law (1972-73), 46, 353-364. London: Oxford University Press.

Talimonchik, V. P. (2008). Resolutions of International Organizations in the Legal System of Russia. Jurisprudence, 5, 134-141.

Tiunov, O. I. (2004). Generally Recognized Principles and Norms of International Law: Notion and their Role in Decisions of the RF Constitutional Court. In M. A. Mitukov, S. V. Kabyshev, \& V. K. Bobrova (Eds.), Generally Recognized Principles and Norms of International Law, International Treaties in Practice of Constitutional Justice: Materials of the All-Russian Meeting (Moscow, 24 December 2002) (pp. 203-209). Moscow: International Relations.

Urova, N. M. (2008). International Civil Procedure Law: Theoretical Basics of Implementation of Norms in the Legal System of the Russian Federation. Moscow: Wolters Kluwer.

Velizhanina, M. Yu. (2007). 'Soft Law': Its Essence and Role in Regulation of International Relations (PhD Thesis). Moscow.

Vlasov, D. N. (2006). Legal Position of International Court of Justice: Notion, Nature and Variants of Display $(\mathrm{PhD}$ Thesis). Ekaterinburg.

Zherebtsov, A. N. (2009). Issues of International 'Soft Law' Norms Realization in the Administrative Mechanism of Regulation of the Population Migration. Administrative and Municipal Law, 7, 13-16.

Zimnenko, B. L. (2006). International Law and the Legal System of the Russian Federation. Moscow: RAP, Statut.

\section{Notes}

Note 1. "On Transplantation of Human Organs and/or Tissues": RF Law of 22 Dec. 1992 No 4180-1 (as amend. on 29.11.2007) in Bulletin of the Congress of People's Deputies and the Supreme Court of the Russian Federation (hereinafter: VSND and VS RF). 1993. No 2. Item 62; SZ RF. 2007. No 49. Item 6040.

Note 2. RF Penal Execution Code of 8 Jan. 1997 No 1-FZ (as amend. on 30.12.2012) in Compilation of Legislation of the Russian Federation (hereinafter: CL RF). 1997. No 2. Item 198; 2012. No 53 (part 1). Item 7638 .

Note 3. "On the Continental Shelf of the Russian Federation": Federal Law of 30 Nov. 1995 No 187-FZ (as amend. on 30.12.2012) in CL RF. 1995. No 49. Item 4694; 2012. No 53 (part 1). Item 7648.

Note 4. "On Countermeasures against Illegally Gained Income Laundering (Legitimization) and Terrorism Financing": Federal Law of 7 Aug. 2001 No 115-FZ (as amend. on 03.12.2012) in CL RF. 2001. No 33 (Part I). Item 3418; 2012; No 50 (part 4); Item 6954.

Note 5. "On Circulation of Medicines": Federal Law of 12 Apr. 2010 No 61-FZ (as amend. on 25.06.2012) in CL RF. 2010. No 16. Item 1815; 2012. No 26. Item 3446.

Note 6. "On Culture": RF Fundamentals of the Legislation of 9 Oct. 1992 No 3612-1 (as amend. on 08.05.2010) in VSND and VS RF. 1992. No 46. Item 2615; CL RF. 2010. No 19. Item 2291.

Note 7. "On Communication": Federal Law of 7 July 2003 No 126-FZ (as amend. on 25.12.2012) in CL RF. 2003. No 28. Item 2895; 2012. No 53 (part 1). Item 7578.

Note 8. Constitution of the Adygei Republic of 10 March 1995 (as amend. on 06.06.2012) in Gazette ZS-Parliament RA. 1995. No 16; 2012. No 16; Constitution of the Republic Buryatia of 22 Febr. 1994 (as amend. on 27.06.2012) in Buryatia. 1994. No 43; 2012. No 66; Charter of Ryazan Oblast of 18 Nov. 2005 No 115-OZ 
(as amend. on 28.12.2012) in Ryazan Gazette. 2005. No 251-252; 2012. No 249-250.

Note 9. "On Postal Communication": Federal Law of 17 July 1999 No 176-FZ (as amend. on 06.12.2011) in CL RF. 1999. No 29. Item 3697; 2011. No 50. Item 7351.

Note 10. "On Foreign Investments in the Russian Federation": Federal Law of 9 July 1999 No 160-FZ (as amend. on 06.12.2011) in CL RF. 1999. No 28. Item 3493; 2011. No 50. Item 7351.

Note 11. "On International Treaties of the Russian Federation": Federal Law of 15 July 1995 No 101-FZ (as amend. on 25.12.2012) in CL RF. 1995. No 29. Item 2757; 2012. No 53 (part 1). Item 7579.

Note 12. "On Development and Signing of International Intergovernmental Acts Beyond International Treaties of the Russian Federation": Enactment approved by the RF Government of 7 Feb. 2003 No 79 in CL RF. 2003. No 7. Item 647.

Note 13. "On Supplementary Guarantees of Protection of the Rights, Freedoms and Legitimate Interests of Individuals Suspected or Accused of Committing Crimes": Decree of the RF President of 12 July 2005 No 796 (as amend. on 31.10.2009) in CL RF. 2005. No 29. Item 3037; 2009. No 45. Item 5318.

Note 14. "Strategy for the Development of the Information Society in Russia": approved by the RF President on 7 Feb. 2008 No Pr-212 in Russian Newspaper. 2008. No 34.

Note 15. "On Strengthening Control Over the Export of Specific Types of Nuclear Facilities, Equipment and Technologies": Ruling of the RF Government of 4 Dec. 2009 No 992 (as amend. on 27.12.2011) in CL RF. 2009. No 50. Item 6100; 2012. No 2. Item 282.

Note 16. "On Implementation of Vienna Document 2011 on Confidence- and Security-Building Measures": Ruling of the RF Government of 4 June 2012 No 545 in CL RF. 2012. No 24. Item 3182.

Note 17. "On the Organization of Activity of the State Commission for Assistance in Achieving a Political Settlement of the Transnistrian Conflict": Decree of the RF President of 8 Aug. 2000 No 1462 (as amend. on 20.09.2000) in SZ RF. 2000. No 33. Item 3352; 2000. No 39. Item 3857.

Note 18. "On Work group of the Ministry for Health and Social Development on the Expert Examination of Legal Acts which establish sanitary and epidemiological requirements regarding their compliance with international standards, recommendations and other documents of international organizations": Order of the RF Ministry of Health and Social Development of 29 Apr. 2011 No 378 in Database "Consultant Plus».

Note 19. "Methodological Recommendations concerning the Organization of Work on the Enforcement of International Legal Obligations of the Russian Federation in the Sphere of Legal Aid": Order of the RF Ministry for Justice of 24 Dec. 2007 No 249 in Bulletin of the RF Ministry for Justice. 2008. No 1.

Note 20. "On the Judicial System of the Russian Federation": Federal Constitutional Law of 31 Dec. 1996 No 1-FKZ (as amend. on 25.12.2012) in CL RF. 1997. No 1. Item 1; 2012. No 53 (part 1). Item 7572.

Note 21. Ruling of the RF Constitutional Court of 23 May 1995 No 6-P in Herald of the Constitutional Court (hereinafter: Herald). 1995. No 2-3.

Note 22. A/RES/40/34, Declaration of Basic Principles of Justice for Victims of Crime and Abuse of Power, adopted by GA resolution 40/34 of 29 Nov. 1985. Retrieved Feb. 7, 2013, from http://www.un.org/documents/ga/res/40/a40r034.htm

Note 23. Ruling of the RF Constitutional Court of 28 Feb. 2008 No 3-P in Herald. 2008. No 3.

Note 24. Bangalore Principles of Judicial Conduct (Annex to E/2006/23). Economic and Social Council Official Records 2006, Suppl. No. 1, UN New York, 2007 (E/2006/99(SUPP).

Note 25. Basic Principles on the Independence of the Judiciary, adopted by the $7^{\text {th }}$ UN Congress on the Prevention of Crime and the Treatment of Offenders held at Milan 26 Aug. - 6 Sept. 1985 and endorsed by GA resolutions 40/32 29 Nov. 1985 and 40/146 13 Dec. 1985. Retrieved Feb. 7, 2013, from http://www2.ohchr.org/english/law/indjudiciary.htm

Note 26. Rec. No. R (94) 12 of the Committee of Ministers to Member States on the Independence, Efficiency and Role of Judges, adopted by the Committee of Ministers on 13 Oct. 1994 at the 518th meeting of the Ministers' Deputies). Retrieved Feb. 7, from https://wcd.coe.int/com.instranet.InstraServlet?command=com.instranet.CmdBlobGet\&InstranetImage=534553 $\&$ SecMode $=1 \&$ DocId $=514386 \&$ Usage $=2$

Note 27. European Charter on the Statute for Judges, 1998. Retrieved Feb. 7, 2013, from 
https://wcd.coe.int/ViewDoc.jsp?id=1766485

Note 28. Dissenting Opinion of Judge B.S. Ebzeev on the Determination of the RF Constitutional Court of 11 March 2005 No 148-O in Herald. 2005. No 5.

Note 29. Determination of the RF Constitutional Court of 5 March 2009 No 544-O-Pin Herald. 2009. No 5.

Note 30. Body of Principles for the Protection of All Persons under Any Form of Detention or Imprisonment, A/RES/43/173. Retrieved Feb. 7, 2013, from http://www.un.org/documents/ga/res/43/a43r173.htm

Note 31. Determination of the RF Constitutional Court of 27 Dec. 2005 No 523-O in Herald. 2006. No 3.

Note 32.Determination of the RF Constitutional Court of 13 June 2002 No 166-O in Database "Consultant Plus».

Note 33. Determination of the RF Constitutional Court of 30 Sept. 2010 No 1421-O-O in Herald. 2011. No 2.

Note 34. Speech given by Mr Valery D. Zorkin, President of the Constitutional Court of the Russian Federation, on the Occasion of the Opening of the Judicial Year, 21 Jan. 2005. In Annual report 2004 of the ECtHR, Council of Europe. Strasbourg, 2005.

Note 35. "On Courts of General Jurisdiction in the Russian Federation": Federal Constitutional Law of 7 Feb. 2011 No 1-FKZ (as amend. on 01.12.2012) in CL RF. 2011. No 7. Item 898; 2012. No 49. Item 6746.

Note 36. Determination of the RF Supreme Court of 11 Oct. 2006 No 78-G06-28 in Database "Consultant Plus».

Note 37. "On Application of the Generally Recognized Principles and Norms of International Law and International Treaties of the Russian Federation": Ruling of the RF Supreme Court Plenum of 10 Oct. 2003 No 5 in Bulletin of the RF Supreme Court (hereinafter: Bulletin). 2003. No 12.

Note 38. Decision of the RF Supreme Court of 20 Feb. 2012 No AKPI 12-22 in Database "Consultant Plus».

Note 39.Decision of the RF Supreme Court of 6 Nov. 2007 No ГКPI 07-1194 in Database "Consultant Plus».

Note 40.Decision of the RF Supreme Court of 10 May 2011 No ГKPI 11-384 in Database "Consultant Plus».

Note 41. Decision of the RF Supreme Court of 26 June 2000 No ГКРI 00-543 in Bulletin. 2000. No 12.

Note 42. Decision of the RF Supreme Court of 7 Feb. 1997 in Database "Consultant Plus».

Note 43. Decision of the RF Supreme Court of 21 Jan. 2002 No ГКРI 2001-1420, 1422, 1753 in Bulletin. 2003. No 4.

Note 44. "On Practice of Application of Measures of Compulsion of Medicine Character by Courts": Ruling of the RF Supreme Court Plenum of 7 Apr. 2011 No 6 in Bulletin. 2011. No 7; "On Judicial Practice on Criminal Cases Regarding Extremist Crimes": Ruling of the RF Supreme Court Plenum of 28 June 2011 No 11 in Bulletin 2011. No 8; "On Judicial Practice on Cases Regarding Defense of Citizens' Honor and Dignity and also of Citizens and Legal Entities' Business Reputation": Ruling of the RF Supreme Court Plenum of 24 Feb. 2005 No 3 in Bulletin. 2005. No 4.

Note 45. "On Confirmation of the Program of Raising of Effectiveness of Arbitrazh Courts Activityin 1997-2000 and of the Plan of Arrangements on the Program Realization: Order of the RF Supreme Arbitrazh Court of 18 Sept. 1997 No 14 in Herald of the RF Supreme Arbitrazh Court. 1997. No 11.

Note 46. Ruling of the Federal Arbitrazh Court of the East Siberian District of 24 Mar. 2005 No A33-6954/04-C6-F02-377/05-C1， A33-6954/04-C6-F02-378/05-C1， A33-6954/04-C6-F02-1149/05-C1 in Database "Consultant Plus».

Note 47. Ruling of the Presidium of the Supreme Arbitrazh Court of Dec. 2012 No 9125/10 on the case NoA19-13262/09-65 in Herald of the RF Supreme Arbitrazh Court. 2011. No 4.

Note 48. Determination of the RF Constitutional Court of 19 Jan. 2005 No 29-O in Herald. 2005. No 4.

Note 49. Decision of the Krasnoyarsky Krai court of 14 May 2010 in Database "Consultant Plus».

Note 50. Determination of the RF Constitutional Court of 23 Apr. 2002 No 91-O in Database "Consultant Plus».

\section{Copyrights}

Copyright for this article is retained by the author(s), with first publication rights granted to the journal.

This is an open-access article distributed under the terms and conditions of the Creative Commons Attribution license (http://creativecommons.org/licenses/by/3.0/). 